\title{
Rethinking Riparian Regrowth
}

\author{
Steven J. Smith

\section{Due to variability in riparian regrowth, managers should be cautious in their regrowth expectations, one Idaho study says.}

$\mathrm{M}$ anagement of livestock in riparian ecosystems has been a topic of considerable interest in recent years. As a result, there has been an effort to develop grazing prescriptions for riparian areas that are effective and easily understood. Herbaceous stubble height has been widely used as a properuse criterion that serves both purposes.

Clary and Webster recommended that in the Intermountain West, a minimum stubble height of 4 to 6 inches should remain at the end of the grazing season to maintain plant vigor and provide for bank protection and sediment entrapment. They indicated that utilization of streamside herbaceous forage in the spring should be limited to $65 \%$ of current growth and that cattle should be removed by July $15^{\text {th }}$ to allow for regrowth. Clary found that after that date, plant growth appears to slow considerably on many riparian systems. In southeast Oregon, Sheeter and Svejcar found little regrowth of the riparian community after mid-July.

Managers frequently prescribe higher utilization intensities in early season riparian pastures-assuming that regrowth will result in meeting the 4 to 6 inch criteria by autumn. This is based on the assumption that riparian areas will experience significant regrowth because of moist conditions.

Often times these proper-use criteria (in the form of stubble height) are prescribed over large areas with little or no site-specific information. This practice fails to recognize that there may be significant differences in regrowth responses across different sites within a pasture. Managers should be cautious in their regrowth expectations-particularly if cattle remain in the riparian unit after the period of rapid growth has concluded.

These factors are discussed using some information from a small riparian area in southeast Idaho. The amount of regrowth on different sites within a single grazing unit was evaluated using simple stubble height measurements.

\section{An Idaho Example}

The study was conducted during 1997 along a 1-mile reach of Sublett Creek (Fig. 1), 20 miles east of Malta in southeast Idaho. Sublett Creek is a small, spring-fed stream at $5,400 \mathrm{ft}$ elevation with an average flow of about $6.0 \mathrm{cfs}$ (cubic feet/second). Stream channel types within the study area include both C3 and B4 types. C3 channel types are characterized by a cobble dominated riffle/pool configuration while B4 types are gravel-dominated rapids and scour pools. At this location, the creek ranges from about 4 to 8 feet wide with an associated riparian area ranging from 50 to 100 feet total width.

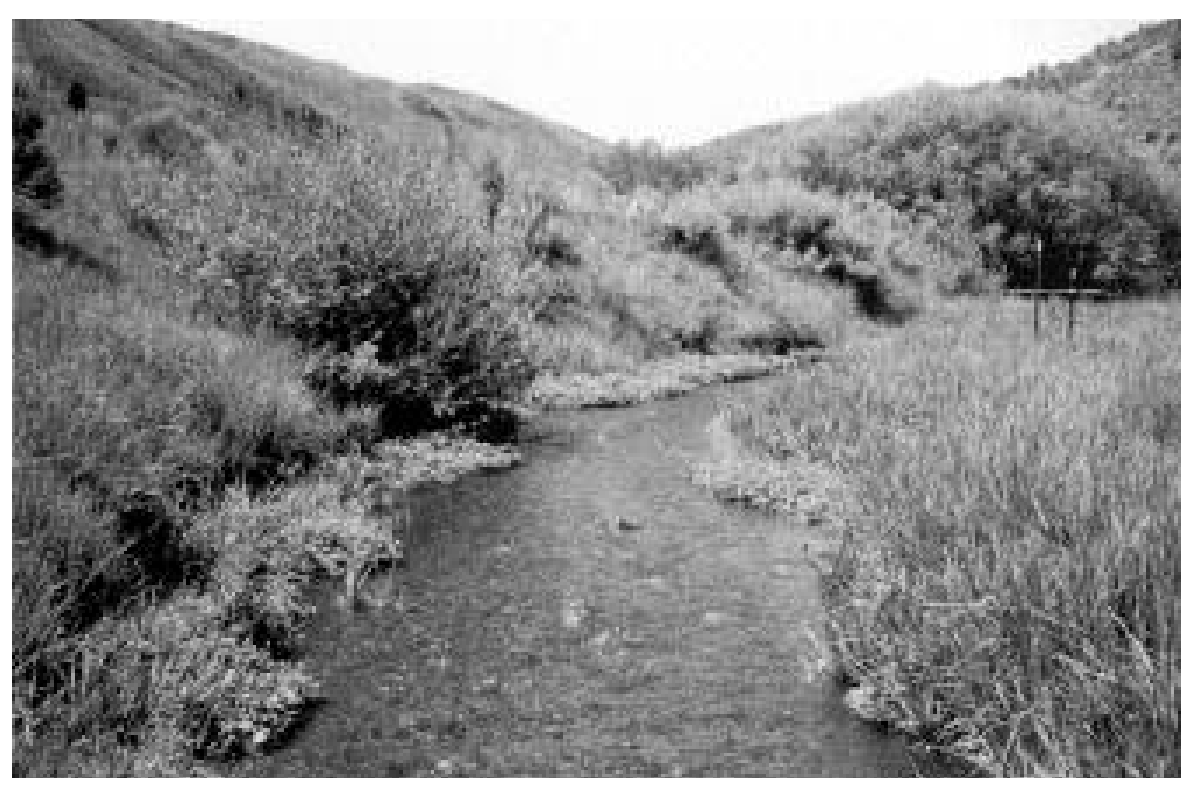

Fig. 1. General view of Sublett Creek.
Soils in the area were derived from limestone parent material and exhibit varied textural classes. Soils are comprised of Loamy mixed Fluventic Haploborolls, Loamy mixed frigid Fluvaquentic Haplaquolls, and Loamy mixed frigid Fluventic Haplaquolls. In general, the surface 10 inches is a silty loam, and between 10 and 20 inches the soil is a silty clay loam. Subsoils consist of sandy loams and gravelly sandy loams. Along the upstream portions of the drainage, there is a thinner surface of silt loam (0-5 inches) and more sand, gravel, and cobble from 5 to 20 inches (the valley bottom is more confined in this area). All soils on the low terraces (abandoned floodplains) were moderately compacted by a combination of livestock and recreation traffic (this was determined by observing platy soil structure). The water table was 13-15 inches from the surface in most areas.

The herbaceous riparian vegetation is 


\section{Common and Scientific Names for Plants}

\begin{tabular}{ll}
\hline \hline Common name & Scientific name \\
\hline Nebraska sedge & Carex nebraskensis \\
Beaked sedge & Carex utriculata \\
Baltic rush & Juncus balticus \\
Watercress & Nasturtium officinale \\
Speedwell & Veronica spp. \\
Seep-spring monkeyflower & Mimulus guttatus \\
Horsetail & Equisetum spp. \\
Redtop & Agrostis stolonifera \\
Kentucky bluegrass & Poa pratensis \\
Canada thistle & Cirsium arvense \\
Booth's willow & Salix boothii \\
Geyer willow & Salix geyeriana \\
Yellow willow & Salix lutea \\
Coyote willow & Salix exigua \\
Woods rose & Rosa woodsii \\
Currant & Ribes spp. \\
Quaking aspen & Populus tremuloides \\
\hline
\end{tabular}

primarily Nebraska sedge, beaked sedge, baltic rush, watercress, speedwell, seep-spring monkeyflower, horsetail, redtop, Kentucky bluegrass, and Canada thistle. Woody species in the community include Booth's willow, Geyer willow, yellow willow, coyote willow, woods rose, currant, and aspen.

Grazing use intensity of herbaceous riparian vegetation has been limited to 35$40 \%$ for several years. Nebraska sedge on all sites exhibited high vigor. Despite moderate soil compaction on the terraces, Kentucky bluegrass vigor was also high.

The area is managed as a riparian pasture in a modified 4-pasture rest-rotation system. During periods when the pasture is in use, the area is grazed from midJune to mid-July.

Total precipitation measured at the Malta, Idaho weather station during 1997 was 14 inches (19\% greater than the 26 year average of 11.3 inches). Rainfall from July through October 1997 was 6.3 inches (44\% greater than the 29 year average of 3.5 inches). July through September rainfall was particularly important for regrowth in the area.

Study plots were installed after 485 cow/calf pairs had occupied the 3,800acre pasture for 30 days. Eight plots were randomly established along a 1mile reach of Sublett Creek. Four were on depositional features (point bars) dominated by Nebraska sedge (Fig. 2). The remaining plots were placed in Kentucky bluegrass meadows on the
Nebraska sedge was grazed/clipped to stubble heights of 8 to 12 inches (about 25 to $40 \%$ utilization). Kentucky bluegrass was grazed/clipped to a 3 to 4 inch stubble height (about $40 \%$ utilization). Plots were established and read on July $15^{\text {th }}$ and $16^{\text {th }}, 1997$ and re-read on October $15^{\text {th }}, 1997$.

\section{Regrowth On Nebraska Sedge and Kentucky Bluegrass Sites}

Sedge plants experienced a mean regrowth of 5.3 inches (Table 1). Two of the plots experienced no regrowth while the other two plots experienced a mean regrowth of 10.7 inches.

At Sublett Creek, spring run-off flows are extremely rare-high water flows typically occur in late summer or early fall after the adjacent upland vegetation desiccates. This was manifested on all the sedge plots where increased flows in early fall inundated the point bars.

On July $15^{\text {th }}$, two of the plots had a water depth of 5 to 6 inches while the other two exhibited soils saturated to field capacity (in a muddy condition). By October $15^{\text {th }}$, all four sedge plots were inundated with 1 to 12 inches of water as flow volumes in the channel increased.

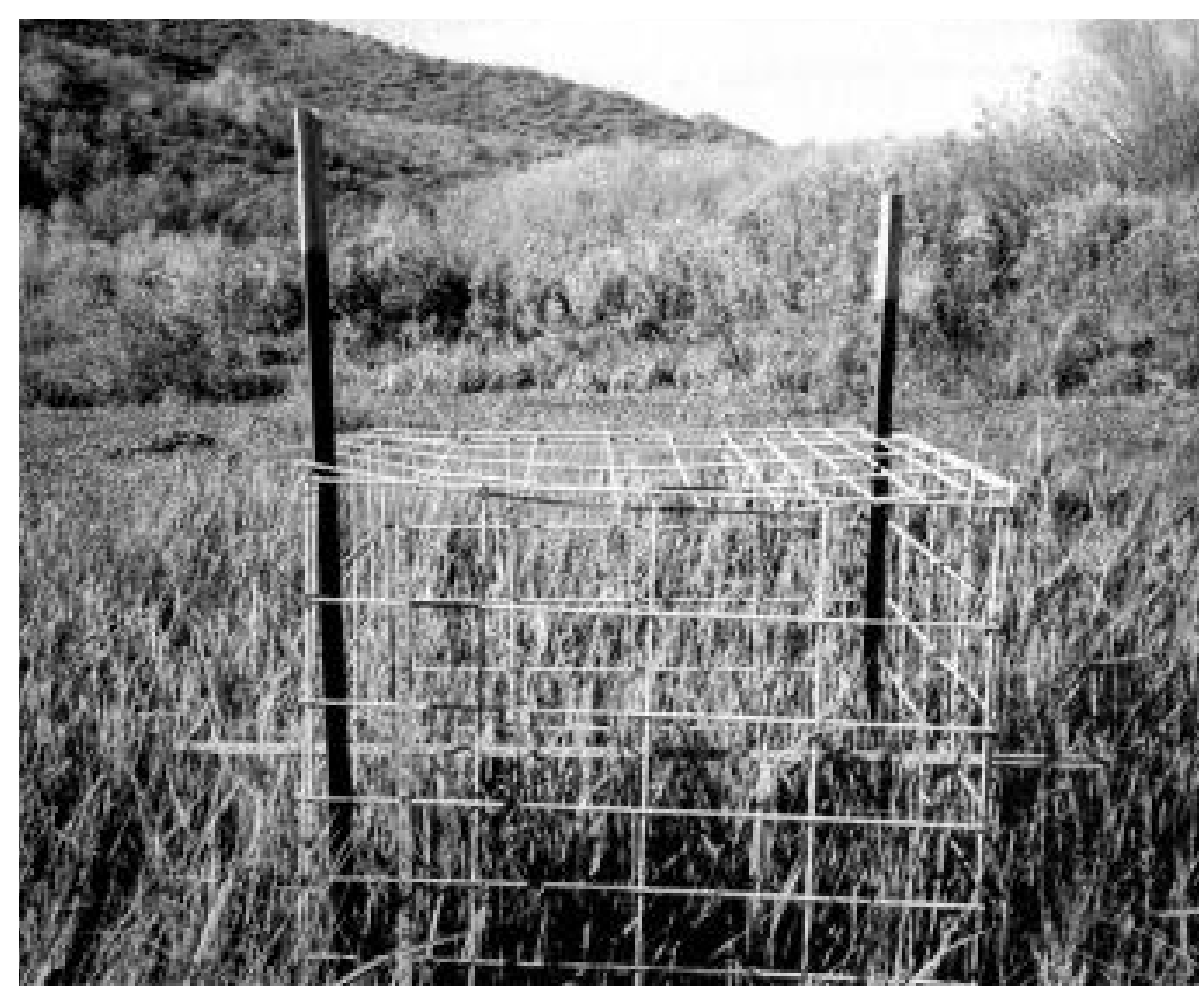

Fig. 2. Typical Nebraska sedge plot along Sublett Creek. 
Table 1. Total herbaceous regrowth on Sublett Creek from July $16^{\text {th }}$ to October $15^{\text {th }}, 1997$.

\begin{tabular}{lccc}
\hline \hline Site & $\mathrm{n}$ & $\overline{\mathrm{X}}$ & $\mathrm{se}$ \\
\hline & & (inches) & (inches) \\
Nebraska sedge & 24 & 5.3 & 1.19 \\
Continuously inundated with water & 12 & 10.7 & .86 \\
Inundated with water only in early fall & 12 & 0 & 0 \\
Kentucky bluegrass & 24 & 2.0 & .20 \\
\hline
\end{tabular}

Of the four plots, regrowth was 10.7 inches in the plots that were inundated with water continuously throughout the growing season. No regrowth occurred in the plots that were saturated in early summer and inundated with water in the fall.

Mean regrowth on the Kentucky bluegrass meadows was about 2 inches. This was consistent regardless of some differences in soil textures among plots. Normal capillary action from the stream combined with above average summer precipitation resulted in high soil moisture throughout the season at these sites.

\section{Regrowth Varies With Climate and Site Conditions}

Although the objective of this study was to determine how site variability affects regrowth, climatic variability can significantly affect regrowth from year

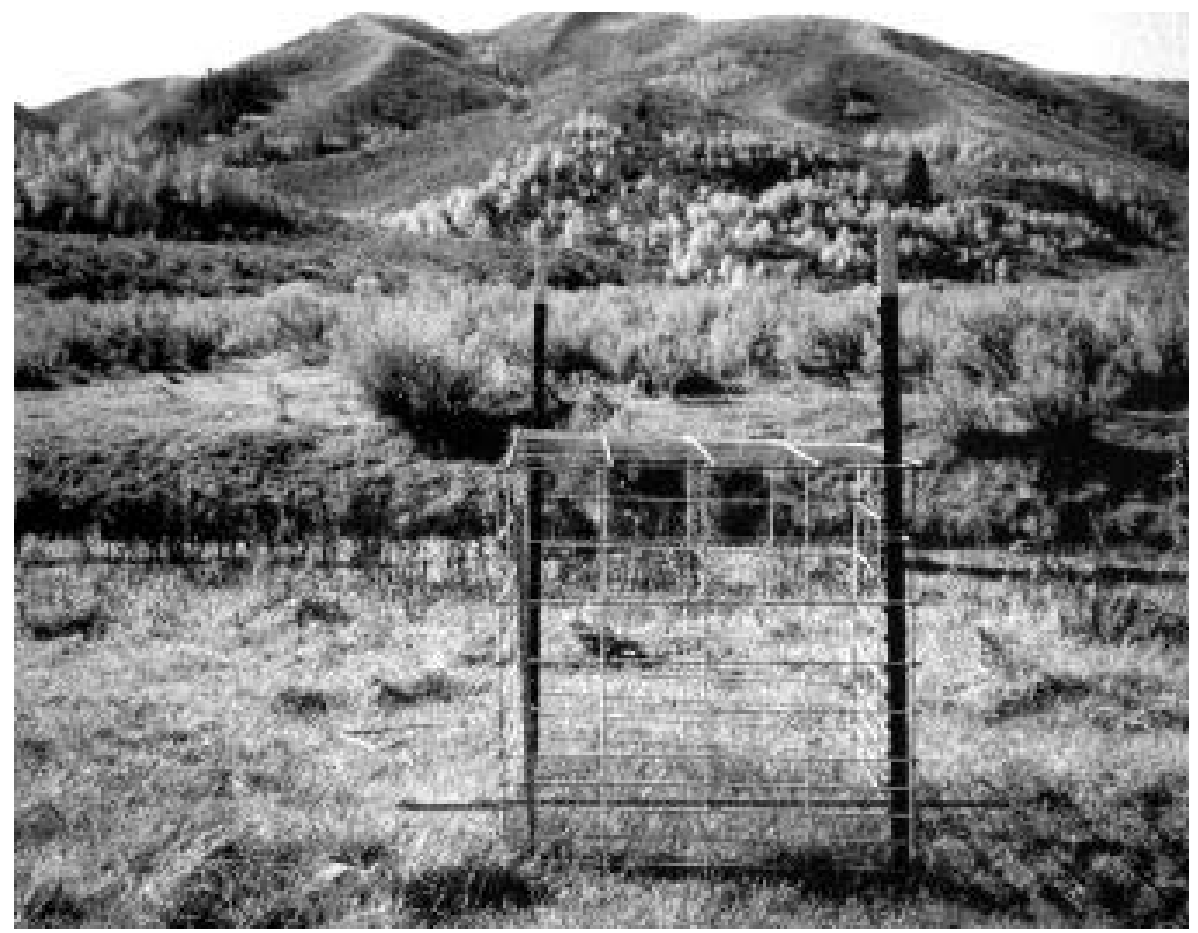

Fig. 3. Typical Kentucky bluegrass plot on terrace meadows adjacent to Sublett Creek. regrowth may be greater and/or more consistent earlier in the season since plants experience more rapid growth during that period.

Managers should be cautious when prescribing early season stubble height criteria. Because of the variability in regrowth responses, grazing prescriptions should be carefully developed. It should be recognized that there might even be significant differences in regrowth responses within a single grazing unit. Because of this site variability, if regrowth were to be considered, it would be advisable for managers to prescribe use-intensities based on sites with the least potential for regrowth. However, managers should still collect site-specific data to determine how much regrowth can be expected. If managers do not have time to develop site-specific useintensity prescriptions, it may not be advisable to consider regrowth as a factor in grazing management planning.

\section{References}

plant vigor combined with abundant precipitation provided vegetation with very favorable regrowth conditions. At this site, consistent regrowth cannot be expected after mid-July. Depending on site conditions and annual precipitation,

Clary

Clary, W.P. 1996. Riparian plant regrowth-maybe not as much as you think! Proceedings $49^{\text {th }}$ Annual Meeting Society for Range Management, P. 13-14.

Clary W.P. and B. F. Webster. 1992. Managing grazing of riparian areas in the Intermountain Region. GTR INT-263.

Elmore, W. and R. L. Beschta. 1987. Riparian areas: perceptions in management. Rangelands 9(6): 260-265.

Rosgen, D.L. 1994. A classification of natural rivers. Catena 22:169-199.

Sheeter G. and T. Svejcar. 1997. Streamside vegetation regrowth after clipping. Rangelands 19(1):30-31.

Author is supervisory rangeland management specialist, Spearfish/Nemo Ranger District, Black Hills National Forest, 2014 N. Main, Spearfish, South Dakota, 57783. The author would like to thank Dr. Dale Bartos, Wayne Elmore, and Howard Hudak for their valuable input on the manuscript. 